\title{
WITHDRAWAL OF GUILTY PLEAS UNDER RULE 32(d)
}

IN 1953, eighty-three percent of federal criminal convictions restilted from guilty pleas. ${ }^{1}$ The defendants in this great number of cases waived their right to a trial, with all its procedural safeguards. ${ }^{2}$ The prevalence and the consequences of the guilty plea highlight the significance of Federal Rule of Criminal Procedure 32 (d) ${ }^{3}$ under which a trial court may, in its discretion, permit a defendant to withdraw a guilty plea and obtain a trial. ${ }^{4}$ District

1. Of 33,473 convictions in $1953,31,336$ were the result of pleas of guilty or nolo contendere. Annual. Report of the Director of tae Administrative Offices of trie United States Courts 184, 186 (1953); Orfiedd, Criminal Procedure from Arrest To Appeal 297-300 (1947). Pleas of nolo contendere are admissions of the facts alleged in the indictment for the purposes of the case. United States v. Cosentino, 191 F.2d 574 (7th Cir. 1951) ; Harris v. United States, 190 F.2d 503 (10th Cir. 1951). But they have no effect as admissions in any subsequent case. United States v. One Chevrolet Stylemaster Sedan, 91 F. Supp. 272 (D.C. Colo. 1950). But see United States v. Weirton Stecl Co., 62 F. Supp. 961, 962 (N.D. W. Va. 1945) (dictum) (nolo contendere does not admit allegations of charge but merely means defendant does not choose to defend).

2. For a much cited judicial statement of these effects of the plea, see Kercheval v. United States, 274 U.S. 220, 223 (1927). See also Donnelly v. United States, 185 F.2d 559 (10th Cir. 1950), cert. denied, 340 U.S. 949 (1951) (no issue for jury after guilty plea); Godish v. United States, 182 F.2d 342 (10th Cir. 1950) (waiver of trial on the merits) ; United States v. Sturm, 180 F.2d 413, (7th Cir.), cert. denied, 339 U.S. 986 (1950) (waiver of rights against illegal search and seizure and coerced confession); Berg v. United States, 176 F.2d 122 (9th Cir.), cert. denied, 338 U.S. 876 (1949) (waiver of jury trial and double jeopardy; prosecution relieved of burden of proof).

3. Fed. R. CRIMr. P. 32(d) :

"A motion to withdraw a plea of guilty or of nolo contendere may be made only before sentence is imposed or imposition of sentence is suspended; but to correct manifest injustice the court after sentence may set aside the judgment of conviction and permit the defendant to withdraw his plea."

4. For cases holding that withdrawal is at the discretion of the trial court, see, e.g., Friedman v. United States, 200 F.2d 690 (8th Cir. 1952), cert. denied, 345 U.S. 926 (1953) ; Williams v. United States, 192 F.2d 39 (5th Cir. 1951); United States v. Harris, 160 F.2d 507 (2d Cir. 1947). Rule 32(d) has been held not to grant defendants the absolute right to withdraw guilty pleas before sentence, despite the wording of the rule which seems naturally to lead to such an inference. United States v. Goo, 10 F.R.D. 337 (D. Hawaii 1950), aff'd, 187 F.2d 62 (9th Cir.), cert. denied, 341 U.S. 916 (1951). Apparently the courts require a showing of the same grounds for withdrawal whether the motion is made before or after sentence. Ibid. Courts, in determining whether there exists "manifest injustice" allowing withdrawal after sentence, cite as precedent cases deciding motions made both before and after sentencing. See, e.g., United States v. Parrino, 212 F.2d 919 (2d Cir.), cert. denied, 75 Sup. Ct. 46 (1954); Williams v. United States, supra; United States v. Searle, 180 F.2d 209 (7th Cir. 1950).

Other means of nullifying an invalid guilty plea are a motion to set aside or vacate judgment under 28 U.S.C. $\$ 2255$, a writ of habeas corpus, and a writ of error coram nobis. Under $\$ 2255$ the movant may be discharged, have a new trial, or be given at corrected sentence; but $\$ 2255$, like habeas corpus, requires a showing of lack of juriscliction or denial of due process. The writ of error coram nobis is available in federal courts 
court opinions indicate the criteria trial courts generally apply in passing on motions to withdraw. Moreover, a trial court's grant or denial of such a motion is reviewable for abuse of discretion, and numerous appellate court decisions delineate the scope of that discretion.

The disposition of withdrawal motions generally depends upon the view the court takes of the factors which caused the accused to enter the plea. ${ }^{8}$ All courts have accepted as axiomatic the rule that a guilty plea must be given freely and with understanding of the crime charged.7 The reasons are

on similar grounds, but is not limited to persons in custody. Circumstances which are grounds for a 32(d) withdrawal need not constitute denial of due process. For eases indicating the relation between 32(d), habeas corpus, and $\$ 2255$, see United States $\mathrm{v}$. Parrino, 203 F.2d 2\$4 (2d Cir. 1953) (motion insufficient under $\$ 2255$ but might qualify under 32(d)); United States v. Shailer, 202 F.2d 590 (2d Cir. 1953) ( 2255 motion considered also under 32(d)); White v. United States, 190 F.2d 365 (6th Cir. 1951) (insufficient application for habeas corpus treated as motion under 32(d)) ; United States v. Gallagher, 183 F.2d 342, 347 (3d Cir. 1950) (concurring opinion) (claim denied under $\$ 2255$ should be made as 32 (d) motion), cert. denicd, 340 U.S. 913 (1951); but see United States v. Paglia, 190 F.2d 445 (2d Cir. 1951) (32(d) withdrawal denied but case remanded for reduction of sentence under $\$ 2255$ ).

For withdrawal as effecting trial on the merits, see United States v. Lias, 173 F.2d 685, 687 (4th Cir. 1949) ; United States v. Shneer, 105 F. Supp. 883, 886 (E.D. P3. 1951).

5. United States v. Shneer, 194 F.2d 598 (3d Cir. 1952); Williams v. United States, 192 F.2d 39 (5th Cir. 1951) ; United States v. Colonna, 142 F.2d 210 (3d Cir. 1944); Camarota v. United States, 2 F.2d 650 (3d Cir. 1924).

6. For a statement of this general rule, see, e.g., United States v. Marcus, 213 F.2d 230, 232 (7th Cir. 1954); Williams v. United States, 192 F.2d 39, 40 (5th Cir. 1951); Rachel v. United States, 61 F.2d 360, 362 (Sth Cir. 1932).

Probable guilt or innocence of the accused has generally been held not to be an issue on motion for withdrawal. Kercheval v. United States, 274 U.S. 220 (1927); United States v. Marcus, supra; Kramer v. United States, 166 F.2d 515 (9th Cir. 194S); United States v. Central Supply Ass'n, 74 F. Supp. 388 (N.D. Ohio 1947). Contra, Cantwell v. United States, 163 F.2d 782 (4th Cir. 1947); United States v. Crawford, 52 F. Supp. 843, 845 (E.D. Pa. 1943) ; United States v. Shailer, 202 F.2d 590, 591 (2d Cir. 1953) (dictum). However, failure at least to allege innocence in motion for withdrawal has been grounds for denial. United States v. Paglia, 190 F.2d 445 (2d Cir. 1951); United States v. Norstrand Corp., 168 F.2d 481 (2d Cir. 1948). See also 61 Hasv. L Rex: 888 (1948); 32 J. CRrar. Law 199, 201 (1941).

7. United States v. Davis, 212 F.2d $26+$ (7th Cir. 1954) ; Friedman v. United States, 200 F.2d 690 (8th Cir. 1952), cert. denied, 345 U.S. 926 (1953); Williams v. United States, 192 F.2d 39 (5th Cir. 1951).

See Fed. R. Criss. P. 11:

"The court may refuse to accept a plea of guilty, and shall nut accept the plea without first determining that the plea is made voluntarily with understanding of the nature of the charge."

Rule 11 is declarative of the common law. Fogus v. United States, 34 F.2d 97, 98 (4th Cir. 1929). See also 2 Hawkins, Pleas of the Crown c 31, §2: "And where a person upon his arraignment actually confesses himself guilty, or unadvisedly diseloses the special manner of the fact, supposing that it doth not amount to felony, where it doth, yet the Judges, upon probable circumstances, that such confession may proceed from fear, menace, or duress, or from weakness or ignorance, may refuse to recurd such confession, and suffer the party to plead not guilty." 
obvious and stem primarily from the fundamental policy of protecting the innocent defendant. 8 If the guilty plea results from coercion, its effectiveness as an instrument for attaining truth is severely limited. And misapprehension as to the criminal acts charged may lead a defendant to plead guilty when he is actually responsible only for different acts, which may be either less culpable or entirely innocent. ${ }^{10}$

Certain administrative and judicial practices have been established to insure that guilty pleas are freely and understandingly given. For example, the Federal Bureau of Investigation prohibits its agents from employing violence in dealing with defendants. ${ }^{11}$ Before pleading, defendants in all federal criminal cases must be advised that they may be represented by counsel and, if they are indigent, that they may have counsel appointed for them. ${ }^{12}$ Federal Rule of Criminal Procedure 10 requires that the accused be given a copy of the indictment. ${ }^{13}$ And Rule 11 enjoins judges not to accept a guilty plea without having reasonable grounds to believe that the defendant understands the charge. ${ }^{14}$

8. The same rationalization is used in the analogous situation of coerced confessions. See 3 Wigmore, Evidence $\$ \S 822-35$ (3d ed. 1940).

9. See Wigmore, Evidence $\$ \S 824-35$ (3d ed. 1940). And it is a violation of due process of law within the meaning of both the Fifth and Fourteenth Amendments. E.g., Waley v. Johnston, 316 U.S. 101 (1942); Walker v. Johnston, 312 U.S. 275 (1941); Smith v. O'Grady, 312 U.S. 329 (1941); Hawk v. Olson, 326 U.S. 271, 275-76 (1945) (dictum); Behrens v. Hironimus, 166 F.2d 245 (4th Cir. 1948).

10. See Smith v. O'Grady, 312 U.S. 329 (1941); Bergen v. United States, 145 F.2d 181. (8th Cir. 1944); State v. Maresca, 85 Conn. 509, 83 Atl. 635 (1912).

11. See FloHeRTY, InSIDE the F.B.I. 92 (1943).

12. U.S. Const. amend. VI; FED. R. CRIM. P. 44. Von Moltke v. Gillies, 332 U.S. 708 (1948); Williams v. Kaiser, 323 U.S. 471 (1945). In passing on motions for withdrawal of guilty pleas, courts place great emphasis on presence or absence of counsel. See United States v. Paglia, 190 F.2d 445, 447 (2d Cir. 1951) ; Crowe v. United States, 175 F.2d 799, 801 (4th Cir. 1949); United States v. Shepherd, 108 F. Supp. 721 (D. N.H. 1952).

13. FED. R. CRIM. P. 10. The rule concerns arraignment, and failure to comply with it will not require reversal on appeal unless shown to be prejudicial. Garland v. Washington, 232 U.S. 642 (1914). It is sufficient to show a copy of the indictment to defendant's counsel. United States v. Shepherd, 108 F. Supp. 721 (D.N.H. 1952). And the requirement is waived when the indictment is read to defendant in open court. Ray v. United States, 192 F.2d 658 (5th Cir. 1951).

14. For text of FED. R. CRIM. P. 11, see note 7 supra. Rule 11 has been interpreted to require no specific procedure on the part of the judge, but that he be satisficd under the circumstances that the accused understands the charge. United States v. Davis, 212 F.2d 264 (7th Cir. 1954) ; Taylor v. United States, 182 F.2d 473 (9th Cir.), cert. denicd, 339 U.S. 988 (1950); Michener v. United States, 181 F.2d 911 (8th Cir. 1950); Mayes v. United States, 177 F.2d 505 (8th Cir. 1949); United States v. Shepherd, 108 F. Supp. 721 (D.N.H. 1952).

Accused's lack of counsel or other circumstance may impose on the judge a special duty to inquire into accused's understanding of the charge. Von Moltke v. Gillies, 332 U.S. 708 (1947); Ruebush v. United States, 206 F.2d 810 (10th Cir. 1953); Collins v. United States, 176 F.2d 773 (9th Cir. 1949), cert. denied, 338 U.S. 943 (1950); United States v. Snell, 174 F.2d 580 (10th Cir. 1949). 
When an accused has pleaded guilty without benefit of one of these safeguards, he will more easily sustain the burden of demonstrating that the plea should not stand. ${ }^{15}$ But other circumstances may show that the defendant entered the plea freely and understandingly despite the procedural defect. ${ }^{10}$ And even though ordinary procedural requirements have been met, the defendant will be permitted to withdraw his plea if he can demonstrate that, notwithstanding these precautions, he was coerced or did not comprehend significant elements of the charge. ${ }^{17}$ In Bergen 2 . United States, ${ }^{18}$ a guilty plea made to a charge of conspiracy to defraud was accompanied by accused's written statement of his "moral" innocence. 10 The Sixth Circuit, reversing the trial judge, allowed withdrawal. The court believed that the defendant's statement showed he did not understand the element of intent necessary for conspiracy; rather he thought he was guilty simply because he had done the overt acts charged. ${ }^{20}$ However, where the standard procedural precautions have been taken, courts are reluctant to grant withdrawal motions which allege compulsion or lack of comprehension, ${ }^{21}$ and only compelling evidence will release the defendant from his plea. ${ }^{22}$

The soundness of these judicial rules seems fairly evident. The importance of procedural measures in protecting the defendant from making an involun-

15. See Uveges v. Pennsylvania, 335 U.S. 437 (1948) (habeas corpus granted: lack of counsel and no explanation of consequences of plea); Williams v. Kaiser, 323 U.S. 471 (1945) (habeas corpus granted: lack of counsel before plea); Waley v. Jolunston, 316 U.S. 101 (1942) (conviction invalid if induced by FBI agent's threats); United States v. Davis, 212 F.2d 264 (7th Cir. 1954) (no explanation of charge; remand for hearing on question of understanding); Gannon v. United States, 208 F.2d 772 (6th Cir. 1953) (withdrawal allowed: no explanation of consequences and lack of counsel); Bergen v. United States, 145 F.2d 181, 187 (Sth Cir. 1944) (dictum).

16. Ray v. United States, 192 F.2d 658 (5th Cir. 1951) (indictment read to defendant); Taylor v. United States, 182 F.2d 473 (9th Cir.), cert. denicd, 339 U.S. 988 (1950) (accused acquiesced in lawyer's entrance of plea); United States v. Searle, 180 F.2d 209 (7th Cir. 1950) (from general knowledge, accused presumed to know possible punishment); United States v. Davis, 212 F.2d 264, 271 (7th Cir. 1954) (dissenting opinion) (accused heard court talking to counsel and prosecutor about counts pleaded to).

17. See Waley v. Johnston, 316 U.S. 101 (1942) (despite proper proceedings, habeas corpus will be granted if plea is coerced); Bergen v. United States, 145 F.2d 181 (8th Cir. 1944) (written statement showed misapprehension of charge; withdrawal granted). See also state court withdrawal decisions, e.g., Beard v. State, 227 Ind. 717, 88 N.E.2d 769 (1949) (fear of mob induced plea); State v. Mlaresca, 85 Conn. 509, 83 Atl. 635 (1912) (seeming understanding but poor knowledge of English).

18. 145 F.2d 181 (Sth Cir. 1944).

19. Bergen v. United States, 145 F.2d 181, 183, 186 (Sth Cir. 1944).

20. Id. at 188.

21. See Taylor v. United States, 182 F.2d 473 (9th Cir.), cert. denicd, 339 U.S. 998 (1950); Collins v. United States, 176 F.2d 773 (9th Cir. 1949), cert. denicd, 333 U.S. 943 (1950); United States v. Mfignogna, 157 F.2d 839 (2d Cir. 1946), ccrt. dcricd, 330 U.S. 830 (1947) ; United States v. Shepherd, 108 F. Supp. 721 (D.N.H. 1952) ; ef. Godish v. United States, 182 F.2d 342 (10th Cir. 1950).

22. See cases cited note 17 supra. 
tary or uniformed plea cannot be gainsaid $;^{23}$ and if absence of any such safeguard caused entry of a plea, withdrawal is justified. On the other hand, where these procedures are faithfully followed, the probability that the defendant has understandingly and freely entered the plea seems great enough to warrant making him offer more persuasive evidence than his mere assertions of ignorance of the charge.

Policy becomes less clear and courts seriously disagree when the issue is the proper disposition of withdrawal motions alleging mistake as to the consequences of conviction by the guilty plea. ${ }^{24}$ Such mistake may proceed from a defendant's ignorance of the legal penalties prescribed for the crime with which he is charged. ${ }^{25}$ But the usual cause is a misleading statement by the prosecutor ${ }^{26}$ or other law enforcement officer ${ }^{27}$ or by the accused's counsel. ${ }^{28}$

Often the prosecutor and the accused make a plea bargain-an agreement by which the defendant pleads guilty in return for concessions promised by the prosecutor. ${ }^{29}$ Usually the prosecutor dismisses or does not bring a charge carrying a heavier punishment than the charge to which the accused has pleaded guilty. ${ }^{30}$ Or he may assure the defendant that he will receive a light sentence or probation. ${ }^{31}$ The accused's mistake as to the consequences of his plea may'

23. For judicial statements emphasizing the importance of such procedural safeguards, see Von Moltke v. Gillies, 332 U.S. 708, 721 (1947); Williams v. Kaiser, 323 U.S. 471, 475 (1945); Kercheval v. United States, 274 U.S. 220, 223 (1927); United States v. Davis, 212 F.2d 264, 267 (7th Cir. 1954). See 32 J. CruM. LAw 199 (1941).

24. See, generally, 32 J. Crrm. Law 199, 202 (1941); Note, 79 U. PA. L. Rev. 484, 487 (1931).

25. Gannon v. United States, 208 F.2d 772 (6th Cir. 1953).

26. See United States v. Fox, 130 F.2d 56 (3d Cir.), cert. denticd, 317 U.S. 666 (1942); Ward v. United States, 116 F.2d 135 (6th Cir. 1940); Camarota v. United States, 2 F.2d 650 (3d Cir. 1924).

27. See United States v. Lias, 173 F.2d 685 (4th Cir. 1949) (misleading statement by judge).

28. See United States v. Parrino, 212 F.2d 919 (2d Cir.), cert. denied, 75 Sup. Ct. 46 (1954); Ridgeway v. United States, 205 F.2d 680 (6th Cir. 1953); United States v. Shneer, 105 F. Supp. 883, aff'd, 194 F.2d 598 (3d Cir. 1952).

29. Orfield, Criminal Procedure froms Arrest ro Appent, 297 (1947); Puttrammer, Adainistration of Criminal Law, 171. (1953); Baker, The ProsecutorInitiation of Prosecution, 23 J. CRm. LAw 770, 786-92 (1933) ; Baker, The Prosecuting Attomey: Legal Aspects of the Office, 26 J. Crim. LAw 647, 671-72 (1936); Dash, Cracks in the Eoundation of Criminal Justice, 46 ILI. L. REv. 385, 393-405 (1951): Weintraub \& Tough, Lesser Pleas Considered, 32 J. Cons. Law 506 (1942) ; U.S. NAtional Commission on Law Observance and Enforcentent, Rejort on Crimunal. Procedure 3-4 (1931); U.S. National Commission on Law Opservance and ENFORCEMENT, REPORT ON PROSECUTTON $95-97$ (1931.).

30. See Puttrammer, op. cit. supra note 29, at 171 ; U.S. Natronal Comasission on Law Observance and Enforcenent, Report on Prosecution 95-96 (1931); Dash, supra note 29, at 392-98; Moley, The Use of the Information in Criminal Cases, 17 A.B.A.J. 292, 293 (1931).

The practice is often termed "the lesser plea" or "plea to the lesser offense." Sometimes a felony is dismissed upon plea of guilty to a misdemeanor. This is called "waiv. ing the felony." 
arise when the court disregards the agreement ${ }^{32}$ or the prosecutor does not carry out his promise. ${ }^{33}$

Motions for withdrawal are frequently based upon allegations describing a dishonored plea bargain. ${ }^{34}$ If the prosecutor denies having made any agreement, the court will generally decide that the allegation has not been proved. ${ }^{35}$ Even when the bargain is shown, some courts deny withdrawal, apparently on the theory that the defendant should have known that the court would not be bound by the prosecutor's promise. ${ }^{30}$ Some of these decisions have been appealed and affirmed. ${ }^{37}$ However, other courts permit withdrawal, finding that the plea was entered under mistake. ${ }^{38}$ Appellate courts have also approved this position, ${ }^{39}$ and some trial courts which have not adopted it have been reversed. ${ }^{40}$ The decisions allowing withdrawal recognize that defendants generally believe that a plea bargain will be implemented by both prosecutor and court. ${ }^{\text {.1 }}$

31. See Baker, The Prosecutor-Intitiation of Prosecution, $23 \mathrm{~J}$. CRns. LAv 770, 786 (1933) ; Baker, The Prosecuting Attorney: Legal Aspects of the Offies, $26 \mathrm{~J}$. Crros. LAw 647, 671-72 (1936); U.S. NATional Cousrrssion on Lav Onservance akd Es:FORCEMENT, REPORT ON PROSECUTION 96 (1931).

32. See United States v. Paglia, 190 F.2d 445, 447 (2d Cir. 1951) (dictum); United States v. Fox, 130 F.2d 56, 59 (3d Cir.), cert. denied, 317 U.S. 666 (1942); Ward v. United States, 116 F.2d 135 (6th Cir. 1940); Camarota v. United States, 2 F.2d 650 (3d Cir. 1924).

33. See allegations in Sullivan v. United States, 75 Sup. Ct. 182, 185 (1954); United States v. Paglia, 190 F.2d 445, 446 (2d Cir. 1951); Ziebart v. United States, 185 F.2d 124, 125 (5th Cir. 1950).

34. See, e.g., United States v. Paglia, 190 F.2d 445 (2d Cir. 1951); United States v. Lias, 173 F.2d 685 (4th Cir. 1949); Rosensweig v. United States, 144 F.2d 30 (9th Cir.), cert. detied, 323 U.S. 764 (1944).

35. See Kramer v. United States, 166 F.2d 515 (9th Cir. 1948); Rosensweig v. United States, supra note 34; but see United States v. Paglia, 190 F.2d 445 (2d Cir. 1951) (withdrawal under 32(d) denied on other grounds but hearing required under $\$ 2255$ to determine question of prosecutor's alleged inducement). However, even without prosecutor's denial, court may disbelieve unsupported allegations of prisoner. Ammons v. King, 136 F.2d 318 (8th Cir. 1945).

36. See United States v. Fox, 130 F.2d 56 (3d Cir.), cert. denied, 317 U.S. 666 (1942); Ward v. United States, 116 F.2d 135 (6th Cir. 1940); Camarota v. United States, 2 F.2d 650 (3d Cir. 1924); cf. United States v. Domroe, 129 F.2d 675 (2d Cir. 1942).

37. United States v. Fox, 130 F.2d 56 (3d Cir.), cert. denied, 317 U.S. 666 (1942); cf. Camarota v. United States, 2 F.2d 650 (3d Cir. 1924) (but lower court reversed on other grounds). See 32 J. Crns. Law 199, 200 (1941).

38. United States v. Lias, 173 F.2d 685 (4th Cir. 1949).

39. Ibid.

40. Ward v. United States, 116 F.2d 135 (6th Cir. 1940); cf. Zicbart v. United States, 185 F.2d 124 (5th Cir. 1950); United States v. Rossi, 39 F.2d 432 (9th Cir. 1930) semble.

41. See United States v. Lias, 173 F.2d 685 (4th Cir. 1949); Ward v. United States, 116 F.2d 135 (6th Cir. 1949); see also 32 J. Crar. LAw 199, 200 (1941). It is unreasonable to assume that defendants are aware of the separate legal powers of prosecutor and judge. 
When the mistake alleged is caused by statements of the accused's own counsel, trial courts do not usually allow withdrawal. ${ }^{42}$ Where the attorney did not categorically tell the defendant what his punishment would be, these holdings are uniformly affirmed. Appellate courts in such cases characterize the lawyer's statements as mere predictions or opinions ; ${ }^{43}$ consequently, mistake could not have caused the defendant to enter the plea, since he is presumed to have known that he might receive the maximum punishment. $A$ conflict has arisen, however, in the few cases where the accused has relied on definite statements of his counsel.44 Two circuit court decisions affirmed denial of withdrawal in such a situation. ${ }^{45}$ But the Third Circuit Court of Appeals enunciated a different rule in United States $v$. Shneer.40 While affirming denial of a withdrawal motion, the court suggested that the district court review the evidence to determine whether the attorney had conclusively stated to the defendant that he would not go to jail if he abandoned his not guilty plea. ${ }^{47}$ With this as a guide, the district court took further evidence, found definite statements, and permitted withdrawal. ${ }^{48}$

The defendant will generally be unable to prove an allegation of mistake which is not based upon a dishonored plea bargain or a definite and misleading statement of counsel. ${ }^{49}$ However, unusual circumstances may exist which will enable him to establish the mistake. A change of plea will then probably be permitted. In Gannon $v$. United States, ${ }^{50}$ the defendant pleaded guilty to possessing narcotics. The language of his plea indicated that he expected to be committed to the Federal Narcotics Farm, ${ }^{51}$ where he had been sent after

42. See United States v. Goo, 10 F.R.D. 332 (D. Hawaii 1950), aff'd, 187 F.2d 62 (9th Cir.), cert. denied, 341. U.S. 916 (1951) ; United States v. Sehon Chinn, 74 F. Supp. 189 (S.D.W. Va. 1947), aff'd, 163 F.2d 876 (4th Cir. 1947); but sie United States v. Shneer, 105 F. Supp. 883 (E.D. Pa.), aff'd, 194 F.2d 598 (3d Cir. 1952).

43. See Futterman v. United States, 202 F.2d 185, 186 (D.C. Cir. 1952); United States v. Searle, 180 F.2d 209 (7th Cir. 1950); United States v. Weese, 145 F.2d 135, 136 (2d Cir. 1944).

44. For discussion of what is a "definite" statement, see United States v. Shncer, 194 F.2d 598, 601 (3d Cir. 1952); see also United States v. Parrino, 212 F.2d 919, 921 (2d Cir.), cert. denied, 75 Sup. Ct. 46 (1954); Futterman v. United States, 202 F.2d 185, 186 (D.C. Cir. 1952).

45. United States v. Parrino, supra note 44 (counsel said conviction would not be basis for deportation); Ridgeway v. United States, 205 F.2d 680 (6th Cir. 1953) (counsel said sentence would be probation); contra, United States v. Davis, 212 F.2d 264 (7th Cir. 1954).

46. 194 F.2d 598 (3d Cir. 1952).

47. United States v. Shneer, 194 F.2d 598, 602 (3d Cir. 1952).

48. United States v. Shneer, 105 F. Supp. 883 (E.D. Pa. 1952).

49. See, e.g., denial of motions in United States v. Panebianco, 208 F.2d 238 (2d Cir. 1953), cert. dentied, 347 U.S. 913 (1954); Futterman v. United States, 202 F.2d 185 (D.C. Cir. 1952) ; United States v. Searle, 180 F.2d 209 (7th Cir. 1950); United States v. Denniston, 89 F.2d 696 (2d Cir.), cert. denied, 301 U.S. 709 (1937).

50. 208 F.2d 772 (6th Cir. 1953).

51. Gannon v. United States, 208 F.2d 772, 774 (6th Cir. 1953). 
a prior conviction for the same crime. ${ }^{62}$ Although he was again sentenced to the Farm, another information was brought, charging him with being a second offender. ${ }^{53}$ After conviction on this information, Gannon moved to vacate that judgment, stating that he wished to withdraw the guilty plea which had made him a second offender. ${ }^{54}$ The district court denied withdrawal, Sixth Circuit reversed on the grounds that the court had not explained the second offender penalties to Gannon and that he had not properly waived his right to counsel. ${ }^{56}$ Mistake was clearly shown, but by circumstances rare in the federal courts.

A new restriction upon withdrawal has been established by the Second Circuit in Parrino v. United States. ${ }^{57}$ There the defendant entered a plea of guilty to a charge of conspiracy to kidnap, ment that conviction could not be the basis for deportation proceedings. When such proceedings were begun, Parrino moved to withdraw his plea. ${ }^{\text {co }}$ The Second Circuit affirmed the district court's dismissal of the motion. . $^{2}$ One ground for its holding was that mistake as to deportation did not require the trial court to allow withdrawal, since deportation was simply a "collateral consequence" of conviction."2 Apparently the court regards as "collateral" all consequences other than sentence and punishment in the particular case. ${ }^{63}$ In contrast, the Gannon decision directed the district court to permit withdrawal where the defendant was ignorant of second offender penalties which were to be imposed in a subsequent proceeding. ${ }^{\text {it }}$

Perplexing policy conflicts must be resolved by a court in passing on withdrawal motions alleging mistake as to consequences. Finality of judicial procedures is a basic consideration opposed to withdrawal. ${ }^{\circ 5}$ Nevertheless, it is

52. Ibid.

53. Id. at 773 .

54. Ibid.

55. Id. at 772 .

56. Id. at 774 .

57. 212 F.2d 919 (2d Cir.), cert. denied, 75 Sup. Ct. 46 (1954).

58. Parrino v. United States, 212 F.2d 919 (2d Cir.), cert. denied, 75 Sup. Ct. 46 (1954).

59. Id. at 921,923 n.6.

60. Id. at 921 .

61. Id. at 922 . Frank, J. dissented with opinion. Ibid.

62. Id. at 921-22. The alternate ground was that the defendant's mistake had been caused by his counsel's statements, and hence could not justify withdrawal. See text at notes 44-45 supra.

63. Id. at 922. See Note, 59 YAlE L.J. 786 (1950), for a list of consequences of conviction. See also United States v. Morgan, 346 U.S. 502, $512-13$ (1954); and statement of Judge Learned Hand in United States "v. Parrino, 203 F.2d 234, 285 (2d Cir. 1953): "followed by deportation, a consequence that under the circumstances will be substantially the equivalent of adding the punishment of exile to that prescribed by the statute."

64. See text at notes 50-56 supra.

65. See United States v. Parrino, 212 F.2d 919, 922 (2d Cir.), cert. denied, 75 Sup. Ct. 46 (1954). See also Rogge \& Gordon, Habeas Corpus, Ciril Rights, and the Fedcral System, 20 U. CHI. L. Rev. 509 (1933); 32 J. CRnc. LAW 199, 202 (1941). 
clear that withdrawal should be permitted where the accused has pleaded in reliance on untrue representations of the prosecutor. ${ }^{60}$ An innocent person may enter into a plea bargain, believing that he would be convicted anyway and might receive a substantially greater penalty. ${ }^{67}$ When the anticipated benefit is withheld, it is manifest injustice not to allow withdrawal. And withdrawal cannot be restricted to defendants whom the judge believes innocent, since courts may not pass on the question of guilt in applying procedural remedies. ${ }^{68}$ Additional support for withdrawal can be found in the desirnbility of maintaining the efficacy of plea bargaining as a tool in the administration of criminal justice. ${ }^{69}$ Prosecutors work within limited budgets, and plea bargaining appears necessary to enable them to dispose of the many cases which arise. ${ }^{70}$ An accused criminal will be reluctant to enter into a plea bargain if he cannot withdraw his guilty plea when the expected restilt of the bargain is not forthcoming. ${ }^{71}$

66. See Baker, The Prosecuting Attorney: Legal Aspects of the Office, $26 \mathrm{~J}$. Crum. Law 647, 672 (1936); 26 J. Crum. Law 457, 458 (1936); 32 J. Crim. Law 199, 202 (1941).

The following rule is laid down in Rachel v. United States, 61 F.2d 360, 362 (8th Cir. 1932): The appellant must show "that the plea of guilty should not be allowed to stand against him because of some reason existing when it was entered, but for which he would not have entered the plea, and that reason must amount to a fraud or an in!position upon him, or a misapprehension of his legal right."

67. See Borchard, Convicting the Innocent 112, 367 (1932): the cases of John A. Johnson (fear of mob violence induced plea from innocent man) and of James Willis (with strong case against him, innocent accused pleaded guilty in hope of leniency); Dash, Cracks in the Foundation of Criminal Justice, 46 ILL. L. REv. 385, 392-95, 401 (1951); Oppenheim, Waiver of Jury Trial in Criminal Cases, 25 Micr. L. Rev. 695, 716-17 (1927) ; Notes, 50 YALE L.J. 499, 504-06 (1941) ; 28 YALE L.J. 168, 170 (1918); 64 HARv. L. Rev. 1376, 1377-78 (1951).

68. See note 6 supra. See United States v. Claudy, 204 F.2d 624, 627 (3d Cir. 1953); Emerson \& Haber, Political and Civil Rights in the United States 103 (1952). See also dissenting opinion of Frankfurter, J., in United States v. Rabinowitz, 339 U.S. 56, 82 (1950): "By the Bill of Rights the founders of this country subordinated police action to legal restraints, not in order to convenience the guilty but to protect the innocent. Nor did they provide that only the innocent may appenl to these safeguards."

69. For advantages and drawbacks of the prosecutor's discretion to bargain, see Orfield, Crininal Procedure from Arrest to Appeal 299-300 (1947) ; PuttKammer, Administration of Criminal Law 171 (1953); Baker, The Prosecutor-Initialion of Prosecution, $23 \mathrm{~J}$. CRIMr. LAW 770, 786-87 (1933); Moley, The Use of the Information in Criminal Cases, 17 A.B.A.J. 292, 293 (1931); Weintraub \& Tough, Lesscr Pleas Considered, 32 J. CRIMr. LAw 506, 529 (1941); 32 J. CRuM. LAW 199, 202 (1941); and for a vehement attack on the practice in Chicago, see Dash, Cracks in the Fonndation of Criminal Justice, 46 ILL. L. REv. 385, 392-405 (1951).

70. ORFIELD, op. cit. supra note 69, at 299; Baker, supra note 69, at 791; Weintraub \& Tough, supra note 69, at 529; U.S. National Commission on LAw OnservanCE ass ENForcement, Report on Prosecution $96-97$ (1931).

71. See Baker, The Prosecuting Attorney: Legal Aspects of the Office, $26 \mathrm{~J}$. Crus. LAw 647, 673 (1936); 32 J. CRIM. LAw 199, 202 (1941). For a recent discussion of withdrawal in England, see 117 Just. P. 620 (1953). 
Even where no plea bargain is involved, a defendant who is able to establish that his plea was entered because of mistake as to consequences should be allowed withdrawal. ${ }^{72}$ Although such change of plea cannot be supported by the administrative policy favoring plea bargains, there still exists the possibility of a guilty plea being entered by an innocent person relying on the security of a known outcome. ${ }^{73}$ This possibility is present whether the mistake concerns "collateral" or "direct" consequences. When the accused can prove that his counsel made conclusive statements to him about material consequences, it is reasonable to infer that these assertions were the cause of the plea. ${ }^{74}$ Hence, if it develops that the lawyer was wrong, withdrawal should be allowed. When the defendant cannot introduce this type of evidence, he will generally be unable to sustain his burden of proof. ${ }^{75}$ However, if he presents other compelling evidence establishing mistake, as the accused did in the Gannon case, ${ }^{76}$ he should be permitted to change his plea. In a society where protection of the innocent individual is deened more important than efficiency in gaining convictions, courts must be willing to permit defendants who have pleaded guilty under clear mistake to have a trial on the merits.

72. See 32 J. Cratr. Law 199 (1941).

73. See Oppenheim, sutpra note 67, at 716-17; Notes, 28 YALE L.J. 16S, 170 (1918); 64 HARv. L. REv. 1376, 1377 (1951); 28 IND. L.J. 374, 377-82 (1953).

74. Weintraub \& Tough, supra note 69, at 529: "The average defendant will not plead guilty unless he feels that he is getting the better of what under any circumstances must be for him a bad bargain." See also United States v. Parrino, 212 F.2d 919, 921, 923 n.6 (2d Cir.), cert. denied, 75 Sup. Ct. 46 (1954); United States v. Parrino, 203 F.2d 284, 285 (2d Cir. 1953) : "Parrino declared that he understood the charge and would plead 'on one condition'' which, however, he withdrew after he had talked with his attorney who was in court."

75. See cases cited note 49 supra.

76. See text at notes 50-56 sipra. 